\title{
OZENA AMONG THE VARIOUS RACES OF THE EARTH.*
}

\author{
DR. J. N. Ror, Nontreal, Canada.
}

Through extensive travels during the last ten years the writer has had the opportunity of coming in contact with the principal peoples of the globe and thus being in a position to study on the spot anatomical, physiological and pathological conditions, believes it of interest to publish his observations and conclusions in regard to ozena. 'l'o escape repetitions, and especially to remain on purely scientific grounds, we shall divide the peoples of the earth, from an ethnical standpoint, into three large families: the white, the black and the yellow. Indeed, if we consider carefully the characteristics of the Malays and the Redskins, we find that the representatives of those two races have had the Nongolians for ancestors. 'The color of their skin, the shape of their eyelids, the development of their malar bones, the flattening of the base of their nose, the thickness of their hair, and generally speaking, their general facial expression, are all arguments in favor of our theory. Moreover, we find in the language of certain Indian tribes of South America a number of expressions very similar to certain Japanese words, and inseriptions and writings, undoubtedly vestiges of those which adorned the shrines of boudha are also often found in Mexican ruins.

We shall have little to say aljout the white race, as such a large number of articles on ozena have already been published; we simply shall draw some conclusions from what we observed in cross-breeds of white with either of the other two races.

The blacks are particularly interesting, and a careful study of them in Africa, America and Occania reveals some very instructive facts. In the course of an extensive voyage around the Dark Continent, we cxamined the nasal cavities of nearly five thousand negroes, in twenty-two different colonies. On several occasions we penetrated into the interior of the country, a long distance from the coast line, and were in a position to visit about a hundred clifferent tribes. After making a most careful and minute examination of those aborigines of Africa, all over the country, we may state, considering the large number that came under our notice, that they do not suffer from ozena. We made a particular study of those races

*Read belore the "Congres fraugais d'oto-rhino-latyngologie," Paris, Any, $191 \mathrm{H}$. 
which are not full-blooded or pure, as the Mulattoes, the Moors of Matnretninit of Arab and particularly of Berber descent, the Peuhls, the Foulals, whose ancestors were the Egyptian Fellahs, the Hottentots and the Bushmen, in whose veins there is a certain quantity of Mongolian blood, the Danakils, Somalis and Crallas, of mixed Arab breed, and finally the Abyssinians who at various periods of their history were often in close contact with the İgyptians. All these peoples showed no signs of atrophic thinitis. 'This disease is also unknown among the negroes we examined in Oceania and in the West Indies, and we had to return to the American continent to find it.

During otre stay in Brazil, where three-quarters of the population is black, in Central America and in the United States, we were surprised to find a large number of cases. We discovered it in pure breeds as well as among the Mulattoes and the Zambis (the offspring of negroes and red-skins).

Our excellent confrères, Doctors Chardinal (of Rio de Janeiro) and Jones (of Newport News, Virginia) also found a number of blacks afflicted with ozena. Their findings show that the disease appears to be less prevalent among the negroes and mulattoes than among the white and yellow races, and we are entircly of that opinion. Their mucous membranes in general are very resistant to infection and it requires a prolonged contact with very virulent microbes to cause a disease.

The yellow race of Asia and its different ramifications which spread practically all over the globe are particularly predisposed to atrophic rhinitis. We found it not only in the Chinese and Japanese, hut also in certain Indo-Chinese of Mongol cross-breed, in the Esquitmos, the Laplanders, the Finlanders, the Malays, the Philippinos, the Hovas and the Redskins. The frequence of the disease varies according to certain conditions which we shall try to explain now in studying the causes of ozena among the different races.

Comlary tis the opinion expressed by F. Fraenkel, Gottstein, Conctoux, lioulay and many other authors, who believe that ozena is preceled by a pre-atrophic hypertrophic rhinitis, we agree with liosworth that stch is not the case. We examined the Chinese in their own country, in tropical climes and in cold countries such as Cinnada in winter, and we did not find that climate was a factor in the frequency of the disease.

By studying a large number of cases, we found, generally speaking, :hat Nomgolians have a tendency to atrophy of the anterior third of 
the inferior turbinal without any pathological symptoms. This is particularly evident if they reside in a hot climate: and in colder countries we find they suffer from hypertrophic rhinitis, though not as often as whites. The Indians of the American continent are predisposed to that kind of atrophy, which is also found in a lesser degree in the cross-breeds. In none of the cases does the enlargement of the inferior turbinal seem to have any influence on ozena, the frequency of which varies according to the more or less contaminated surroundings. Moreover, the African negroes often suffer from hypertrophic rluinitis if they live in a cold, damp clime, though they do not show any lesions in their own country. We were astonished at the frequency with which we observed the deviation of the septum in the yellow race and especially in the Indians, among whom we found it in no less than forty per cent of all those we examined. 'This malformation is also more frequently found in the cross-breeds than in whites.

We scarcely ever found compensatory hypertrophic rhinitis in the largest side of the nasal cavities in the Mongolians; more often ave observed the presence of a muco-purulent discharge with a crusty deposit devoid of odor. This corresponds to a state of pseudo-ozena. In cases of true ozena we found the odor weaker and less repulsive than in whites and blacks. We draw particular attention to this fact and believe it to be due to a physiological increase in the quantity of the nasal secretions proper to that race, which prevents the drying of pus and thus shortens the life of bacteria and partly prevents the formation of their toxines.

'The deviation of the septum in the Mongolians, combined with the formation of non-ozenous mucosities in the much-expanded nasal cavities, is an argument against the theory expressed by Zaufal, who states that atrophic rhinitis is found in those individuals who possess very large nasal cavities, where the weakness of the air draughts allows stagnation and decomposition of the secretions. On the other hand, the negroes-scarcely ever showing any deviation or spurs of the septum--have the arch of their palate lower than in the white and yellow races, the nose flat and broad, with wide nostrils, and in Africa they do not suffer from ozena.

We shall not bring forward arguments to offset the theories of epithelial metaplasia sustained by Siebenmann or against Zarniko's theory of tropho-neurosis, or that of osteo-malacia of Cholewa, of primary infection of the sinus, as advanced by Vieussens-Grundwall; we shall simply repeat that there is no atrophic rhinitis to be found 
among the natives of the Dark Continent. The same may be said about tuberculosis which also exists in those countries.

The infection theory of ozena appears to be the only one which will satisfy every demand. We do not intend to discuss again, as it has already been done on several occasions, the value of the capsulated cocco-bacillus of Löwenberg, of the pseudo-diphtheric bacillus of Belfanti and Della Vedova, and of the small bacillus of Pes and Gradenigo. We believe the cocco-bacillus of Perez (of Buenos Ayres) is really the specific velicle of the in fection, since experiments conducted in the laboratories confirm and prove that theory. The cocco-bacillus when injected into the circulation of an animal is the only one which catses atrophic rhinitis with the characteristic odor of ozena. The other microbes found in the nasal cavities only act as secondary agents.

After examining in both Americas a multitude of Indians belonging to twenty-seven different races, and a large number of cross-breeds, we observed that local conditions and surroundings cause a more or less frequent appearance of the malady. Rare enough in those parts of the country where the natives live on ligh ground seattered in the open air, the disease is found much more frefuently in the towns and on the platin where they live under more congested conditions and breathe impure and contaminated air. Among the latter we even found the disease in about six per cent of the population, and as the women are more confined to their lomes and live in a more secluded manner than the men, they are more often infected. We observed the same conditions in Malasia, China and Japan.

Redskins and cross-breeds are equally infected by ozenal still, the yellow race appears to be more susceptible to the discase than the white. We believe the reason for this conclition is to be found not only in the filth sone of the Mongolian races are addicted to, but also to the want of symmetry in their nasal cavities. The deviation of the septum which we observed very often in then, naturally causes respiratory defects and a greater abundance of stagnant secretions than in the whites-with equal lesions-and the bacillus of Perez finds a field quite prepared for its culture and development.

In Madagascar, our excellent confrères, Dr. Fontoyront and Dr. Roton, were kind enough to show us some cases of truc ozena among the Hovas. It is interesting to note that that race, which is of Malay descent with a slight mixture of Hindu blood, is the only one which shows any susceptibility to the infection, though they come in fairly intimate contact with the negroes who do not yet suffer from that disease. 
That ozena is distinctly of microbic origin is most conclusively proved by observations in Africa. Of all the blacks we examined in that vast continent, not one was infected. Not even among the natives of mixed descent whose ancestors may perhaps have suffered from the disease which probably disappeared through the purifying agency of the sun's rays, in a sand-covered tropical region. And yet, when removed from the slave coast to Brazil-to an equatorial clime, similar to that of their own country-these negroes in contact with the infected aborigines, soon become infected themselves. When transplanted to the northern parts of South America, into Central America or to the United States, they brought the disease with them or contracted it in these countries. 'I'heir mulatto or Zambi descenclants in turn were infected, and according to statistics, these blacks are more often contaminated than those of pure blood. 'l'his is probably due to their closer and more intimate connections with the white and yellow races, and also to the heredity of the diathesis of the later, which in a general manner reduces to a great extent their power of resistance.

It is thus very evident that the blacks are not immune to ozena, and it will be interesting to know how long Africa and Oceania will remain free from contamination, and particularly the West Indies, which would seem to be more exposed to the infection since they are inhabited to a great extent by mulattoes who often visit the American const.

Now, if we are allowed to draw certain conclusions from the olsservations we collected from all quarters of the globe, we may say that ozena is an infectious disease and is found in all races. Yet, the disease is less freruent among the blacks than among the whites, and is most prevalent among the yellow race. The marked deviation of the septum on these latter, to which we must add their state of habitual uncleanliness and nasal irritation, produce in their mucous membrane a splendid breeding-ground for the microbes.

The blacks of Afriea, (Oceania and the West Indies are not yet infected, although they are susceptible to the disease and the small number of Europeans who came under our notice-and they were not afflicted with ozena-..-does not allow us to express an opinion as to the future appearance of the clisease in those countries.

grr Rue St. Denis. 